\title{
Role of Surface Proteins in Staphylococcal Adherence to Fibers In Vitro
}

Ambrose L. Cheung and Vincent A. Fischetti

Laboratory of Bacteriology and Immunology, The Rockefeller University, New York 10021

\begin{abstract}
To study the role of surface proteins in the adherence of Staphylococcus aureus to fibers that are used in tampon and surgical gauze pad manufacture, we have developed an adherence assay with $S$. aureus cells and cotton and rayon fibers. Results suggest that staphylococcal adherence is dependent on both the substrate and the material used to coat these fibers. Scanning electron micrographs supported the adherence results and revealed more cells on the surface of cotton than rayon fibers. Treatment of staphylococcal cells with proteolytic enzymes significantly reduced binding to pure cotton and detergenttreated cotton fibers. Immunoblot analysis of cell wall proteins suggested that surface proteins in the mol wt range of 120-220 $\mathrm{kD}$ were involved in the adherence of $S$. aureus to cotton fibers. Although the adherence of $S$. aureus to cotton fibers alone appeared to be mediated through surface charge or hydrophobic interactions, bacterial binding to fibers which have been pretreated with defibrinated blood appeared to be more specific and independent of the surface constituents of the fibers. The results of these studies implicate staphylococcal surface proteins in the adherence of $S$. aureus to commercially available tampon fibers and surgical gauze pads.
\end{abstract}

\section{Introduction}

Toxic shock syndrome (TSS) ${ }^{1}$ is an acute, severe, multisystem disorder that is characterized by the rapid onset of fever, hypotension, erythroderma, and delayed desquamation of the palms and soles (1). The syndrome has been recognized to occur in a variety of clinical settings. Most commonly, it occurs during the menstrual period, although postsurgical cases have also been reported (2). Epidemiologic studies of TSS have implicated colonization with Staphylococcus aureus ( $S$. aureus) and the use of tampons or surgical gauze pads as risk factors for the development of the syndrome $(1,3,4)$. An extracellular protein of $S$. aureus, TSS toxin-1 (TSST-1), with a mol wt of $22,049 \mathrm{D}$ has been isolated $(1,5)$ and was shown to produce a TSS-like picture in rabbits (6).

The intriguing issue relating to the pathogenesis of TSS is

This work was partially presented at the Annual Meeting of the American Society for Microbiology in Miami Beach, FL in May 1988.

Address reprint requests to Dr. Cheung, Laboratory of Bacteriology and Immunology, The Rockefeller University, 1230 York Avenue, New York, NY 10021.

Received for publication 27 June 1988 and in revised form 20 December 1988 .

1. Abbreviations used in this paper: CDM, chemically defined medium; TSS, toxin shock syndrome; TSST-1, toxic shock syndrome toxin-1.

J. Clin. Invest.

(C) The American Society for Clinical Investigation, Inc. 0021-9738/89/06/2041/09 \$2.00

Volume 83, June 1989, 2041-2049 that of the role of tampons and, in some cases, surgical packing in the disease. In particular, the analogous role of postoperative nasal packing and packing of other body cavities to the use of vaginal tampons as a possible risk factor for TSS has been suggested (4). Since cotton fibers were frequently the material used in surgical packing and tampons, it is likely that pertinent findings in the role of tampon fibers in the pathogenesis of TSS may be relevant to cases involving postoperative packing of other body cavities.

It is known that tampons do not appear to enhance the growth of TSS strains in either nutrient broth or in human blood $(2,7,8)$, yet different tampon types can alter the amount of toxin produced in vitro when compared to nontampon controls $(9,10)$. Entrapment of air or increase in surface area as a result of tampon insertion may serve to partially explain the augmented production of TSST-1 toxin by TSS-associated $S$. aureus strains (11). Studies by Ingham et al. (12) implicated a complex interaction of staphylococci with tampon materials under in vitro conditions whereby the metabolic activities of the microorganism are altered. For instance, the production of extracellular products of $S$. aureus such as hemolysin is decreased when the bacteria are grown in broth in the presence of tampon fibers. Holland et al. have reported the effect of solidphase material such as chemically modified cotton on the secretion of extracellular enzymes by a TSS strain (13). Likewise, selective surface proteins of $S$. aureus appeared to be expressed or enhanced in production when grown on a solid surface as compared to those grown in a liquid medium (14). Thus, the microenvironment available to the bacteria is an important determinant in modifying the mode of the metabolic machinery of the microorganism.

Selective change in the metabolic activities of $S$. aureus, including TSS toxin production, under varied growth conditions may be a consequence of the change in the bacterial environment or the selection of a subpopulation of cells as a result of the condition of growth. Ingham et al. (12) demonstrated an apparent decrease in the growth rate of a TSS strain when grown in the presence of cotton fibers, but phase contrast microscopy of the sample revealed the adherence of the bacteria to the cotton materials. This finding indicated that optical density or colony forming unit measurement of the fluid culture may not reflect the true amount of growth in the presence of tampon material. Further, it may be important to investigate if these adherent cells exhibit different physiologic and metabolic functions from those of cells in liquid culture. As a first step to try to understand the phenomenon of adherence of $S$. aureus to fibers used in tampon and surgical packing manufacture, we present in this report that surface proteins of $S$. aureus might be involved in the adherence of staphylococci to these fibers. Further, these proteins may mediate specific adherence through blood components that coat the fibers.

\section{Methods}

Bacterial strains. A toxic shock-associated vaginal isolate (DYAL) is from the Rockefeller University collection. An enzyme-linked immunosorbent assay using monoclonal antibodies specific for TSST-1 
toxin, has confirmed production of the toxin by this strain (15). A staphylococcal blood isolate, strain DB, was employed as a non-TSS associated strain. An Escherichia coli strain, K12 strain C600NR, was from Dr. June Scott at Emory University. The $S$. aureus and E. coli strains were stored at $-70^{\circ} \mathrm{C}$ in chemically defined medium (CDM) (16) with $20 \%$ (vol/vol) glycerol and in brain heart infusion, respectively.

Bacterial growth and harvest. For growth of staphylococcal cells in liquid culture, a loopful of bacteria was inoculated into $50 \mathrm{ml}$ of CDM. Similarly, E. coli was grown in CDM with the addition of 5\% (vol/vol) tryptone yeast extract (17). For radiolabeling cells in liquid culture, 0.5 $\mathrm{ml}$ of $\left[\right.$ methyl $\left.-{ }^{3} \mathrm{H}\right]$ thymidine $(\approx 50 \mathrm{Ci} / \mathrm{mmol} \mathrm{sp}$ act; Amersham Corp., Arlington Heights, IL) was added to yield $10 \mu \mathrm{Ci} / \mathrm{ml}$. After incubating the culture for $16.5 \mathrm{~h}$ at $37^{\circ} \mathrm{C}$ with gyratory shaking $(150 \mathrm{rpm})$ to reach late log or early stationary phase (as predetermined from growth curve analysis), the organisms were collected by centrifugation $(2,000 \mathrm{~g}$ for $10 \mathrm{~min}$ ) and washed thrice with $10 \mathrm{ml}$ of cold PBS; pH 7.4 (PBS). All harvested staphylococcal cells were then dispersed by sonication for 1 min using the microtip ( $10 \%$ power output of a model 380 heat system, sonicator; Ultrasonics; Farmingdale, NY). Preliminary studies indicated that the viability of the staphylococci was not affected by this treatment as confirmed by CFU both before and after sonication. A subsequent gram stain revealed the bacterial suspension to have mostly single cells without cluster formation. To further eliminate any aggregates, the sonicated staphylococci or $E$. coli cells were passed through a 5- $\mu \mathrm{m}$ filter (Schleicher \& Schuell, Inc., Keene, NH) and then adjusted with PBS to an OD of 1.0 at $650 \mathrm{~nm}\left(\approx 1.5 \times 10^{9} \mathrm{CFU} / \mathrm{ml}\right)$ (using an $18 \mathrm{~mm}$ borosilicate culture tube). In some experiments, the cells (OD $=1.0$ ) were heat-killed at $56^{\circ} \mathrm{C}$ for $1 \mathrm{~h}$ and then stored as a suspension with $0.005 \%$ merthiolate. The usual specific radioactivities obtained with strains DYAL, DB, and K12 strain C600NR were $\sim 1,000$ $\mathrm{cpm} / 8-9 \times 10^{6}, 1,000 \mathrm{cpm} / 8 \times 10^{6}$, and $1,000 \mathrm{cpm} / 7 \times 10^{5}$ bacteria, respectively.

Fibers. Fiber disks composed of pure rayon, pure cotton, or natural cotton containing $0.37 \%$ Tween 20 were used in our adherence study. Pure cotton or rayon fibers differ from those found in tampons in that they do not have surfactants necessary for manufacturing purposes. However, pure cotton fibers are usually the material found in surgical gauze pads. In contrast, natural cotton containing $0.37 \%$ Tween 20 (wt \%) as a detergent was similar to the material found in commercially available tampons.

In preparing pure fibers, natural cotton or rayon fibers were carded and refluxed in a soxhlet extraction apparatus with boiling isopropanol for $6 \mathrm{~h}$ to remove the surfactants and other soluble components. The washed fibers were dried in a vacuum oven at $100^{\circ} \mathrm{F}$ and 25 in. of $\mathrm{Hg}$ and then compressed and cut into disks.

Cotton fibers with detergent were prepared by carding natural cotton fibers followed by immersion in a bath with Tween 20 . The prefabricated fibers wère made into disks.

Different disk dimensions were used initially to determine the optimal condition for the adherence experiments. It was found that disks with a diameter of 0.5 in. was optimal in our assay (described below). Since preliminary studies revealed that the adherence characteristics of the fibers did not change even when they were not sterilized with ethylene oxide, assays were performed with unsterilized fibers.

Assay for in vitro bacterial adherence to fibers. Of the several methods tested to effectively remove nonadherent bacteria from the fiber disks, washing the disk repeatedly in a suction apparatus was found to be the most effective as determined by the radioactivity of the final wash. After a period of incubation of usually $30 \mathrm{~min}$ (up to $2 \mathrm{~h}$ depending on the experiment) on an orbital shaker (100 rpm), the disk was removed from a labeled bacterial suspension with a clean forceps and inserted into the graduated funnel (15 ml size) of a Millipore suction filtration apparatus (catalogue 102502; Millipore Corp., Bedford, MA). Suction was then applied to the system followed by five washes of $8 \mathrm{ml}$ PBS each. This number of washes was previously determined to be sufficient to remove all nonadherent organisms since additional washes did not contain radioactive counts. The number of adherent bacteria to the fiber disk was determined by counting the radioactivity in the disk in a $20-\mathrm{ml}$ scintillation vial containing $10 \mathrm{ml}$ of hydrofluor (counting efficiency $\approx 45 \%$ ) (National Diagnostics, Manville, NJ). The radioactivity of a standard suspension of bacteria (with a previously determined CFU) and the fiber disks were counted in a Tricarb liquid scintillation spectrometer (model 3390; Packard Instruments, Downers Grove, IL). With most of the studies, 3\% of the inoculum of the labeled cells showed nonspecific adherence to the glass vials. Preliminary studies also revealed that the presence of cotton disks resulted in a $20 \%$ quenching of radioactive counts while rayon disks did not interfere with counting efficiency. The quenching in radioactivity was treated as a constant in the calculation of staphylococcal adherence to cotton fibers.

To determine the effect of blood or blood products on bacterial adherence to the fibers, in some experiments the fiber disks were preincubated with sterile human blood $(2 \mathrm{ml})$ followed by three washes of $10 \mathrm{ml}$ PBS each to remove excessive blood and serum. In other experiments, the fiber disks were incubated with $2 \mathrm{ml}$ of the following solutions with agitation for $30 \mathrm{~min}$ : (a) serum (from the same donor of blood), (b) human serum albumin (HSA) in various concentrations (Sigma Chemical Co., St. Louis, MO) in PBS, (c) HSA $(10 \mathrm{mg} / \mathrm{ml})$ in PBS with fibronectin $(50 \mu \mathrm{g} / \mathrm{ml}$; Boehringer-Mannheim Biochemicals, Indianapolis, IN), (d) HSA $(10 \mathrm{mg} / \mathrm{ml})$ in PBS with monoclonal mouse $\mathrm{IgG}_{1}(1 \mathrm{mg} / \mathrm{ml}$ ) directed against $\mathrm{M}$ protein (a gift of Dr. Kevin Jones at The Rockefeller University) or (e) control PBS. After incubation, the fiber disks were washed with PBS as described above. All washed fiber disks were then incubated with radiolabeled bacteria (30 min with agitation) and washed with PBS as described. The radioactivity associated with adherent bacteria on the fiber disk was determined as described above.

Experiments were also performed in which the fiber disks were incubated with labeled cells and serum components in a competitive assay. Radiolabeled DYAL cells mixed with serum components were added to cotton disks and allowed to incubated for $\mathbf{3 0} \mathrm{min}$ with agitation. The disks were then washed with PBS and counted for radioactivity.

All experiments were conducted in triplicate. The total weight of three fiber disks (rayon or cotton) was between 70 to $80 \mathrm{mg}$ in all experiments. Within each set of experiments, the total weight of the three fiber disks in triplicate was the same in all samples. The number of adherent cells was derived from a standard curve of counts per minute plotted against the CFU for each bacterial strain tested. Since preliminary studies demonstrated that the adherent property of the bacteria did not change even when they were heat-killed at $56^{\circ} \mathrm{C}$ for 1 $h$, all subsequent experiments with each strain were performed with the same batch of heat-killed cells.

Removal of surface proteins with proteolytic enzymes. To examine the adherent property of cells that have had some or all of their surface proteins removed, bacteria were digested with either trypsin (Sigma) or proteinase K (Boehringer Mannheim) as previously described (14). Reactions were terminated by the addition of $1 \mathrm{ml}$ of soybean trypsin inhibitors ([Sigma] $0.2 \mathrm{mg} / \mathrm{ml}$ in $0.1 \mathrm{M}$ ammonium bicarbonate $\mathrm{pH}$ 8.0) to the trypsin digest or $30 \mu$ l of $0.1 \mathrm{M}$ PMSF to the proteinase $K$ digest. After four washes with cold Tris buffer $(0.05 \mathrm{M}, \mathrm{pH} 7.8)$, cells were sonicated and filtered as described above, and adjusted to an OD of 1.0 with PBS. The bacterial cells were stored at $4^{\circ} \mathrm{C}$ as a suspension in $0.005 \%$ merthiolate.

The presence of residual enzymatic activity in the cells after the final PBS wash was determined by azocoll, a proteolytic substrate, and by digestion of gelatin on an unprocessed Kodak X-omat XAR film as previously described (14).

Extraction of cell-wall proteins with lysostaphin. Bacterial cells collected from centrifugation of $1 \mathrm{ml}$ bacterial suspension (OD of 1.0 at $650 \mathrm{~nm}$ ) were resuspended in $24 \mu \mathrm{l}$ of digestion buffer (30\% raffinose in $0.05 \mathrm{M}$ Tris pH 7.5 with $0.145 \mathrm{M} \mathrm{NaCl}$ ) containing $25 \mu \mathrm{g}$ of lysostaphin (Sigma) and $1 \mu \mathrm{g}$ of deoxyribonuclease (Worthington Biochemicals Co., Freehold, NJ). This concentration of raffinose was employed as a hypertonic medium to stabilize the protoplasts that formed 
during lysostaphin digestion (14). The cell mixture was then allowed to react at $37^{\circ} \mathrm{C}$ for $45 \mathrm{~min}$ with rotatory mixing at $24 \mathrm{rpm}$. To control proteolytic activity from enzymes that may be released by the cells during lysostaphin digestion, iodoacetamide and PMSF were added to yield a final concentration of $1 \mathrm{mg} / \mathrm{ml}$ and $1 \mathrm{mmole} / \mathrm{ml}$, respectively. The supernatant containing the cell wall extract was removed, recentrifuged twice, and stored in aliquots at $-70^{\circ} \mathrm{C}(14)$.

Preparation of antisera for immunoblot. Strain DB, a recent blood isolate, was used to raise antisera because of its minimal passage (twice) in laboratory media. Previous studies have shown that antisera raised in chickens to strain DB crossreact with surface antigens found on other strains of $S$. aureus (14) with minimal background reactions. Briefly, $1 \mathrm{ml}$ of the stock culture of strain DB was spread evenly on a petri dish that contained liquid CDM in a $1 \%$ agar base and allowed to incubate in a moist chamber for $16.5 \mathrm{~h}$ at $37^{\circ} \mathrm{C}$. The bacteria were harvested by scraping directly from the agar surface, washed thrice with PBS, adjusted to an OD of 1.0 as described, heat-killed at $56^{\circ} \mathrm{C}$ for $1 \mathrm{~h}$, and stored in $1-\mathrm{ml}$ aliquots at $-70^{\circ} \mathrm{C}$. Chickens were then immunized with heat-killed staphylococcal cells and bled as previously described (14).

SDS-PAGE and immunoblot analysis. Proteins were separated on 9\% SDS-polyacrylamide gel slabs by the method of Laemmli (18). Molecular weight standards (Pharmacia Fine Chemicals, Piscataway, NJ) were run concurrently in adjacent wells. The standards were ferritin subunit $(220 \mathrm{kD})$, phosphorylase b $(94 \mathrm{kD})$, BSA $(67 \mathrm{kD})$, ovalbumin $(43 \mathrm{kD})$, and carbonic anhydrase $(30 \mathrm{kD})$. After electrophoresis, proteins were electrophoretically transferred onto nitrocellulose (Schleicher \& Schuell) (19). The nitrocellulose immunoblots were reacted with chicken antisera to strain DB or chicken anti-protein A IgG as previously described (14). The reactive bands were visualized as described by Blake et al. (20).

Scanning electron microscopy. Heat-killed strains DYAL or DB were adjusted to an OD of 1 at $650 \mathrm{~nm}$, diluted 1:10 and incubated with either rayon or cotton disks with agitation $(100 \mathrm{rpm}$ on an orbital shaker) for $30 \mathrm{~min}$. The disks were then washed with PBS under suction as described above. Scanning electron microscopy was performed on the fibers according to standard methods (21).

Data and statistics. The amount of adherent bacteria was expressed either as the mean number of attached cells \pm SEM or as the mean percentage of the original inoculum bound \pm SEM. The latter expression of data allowed one to adjust for the slight difference in inoculum size in different samples of the same experiment.

\section{Results}

Site of bacterial adherence to the fibers. Since the fiber disks are composed of a great number of fibers having a relatively large surface area, the possibility existed that the observed adherence was either a consequence of cells attaching to the ends of the fibers or that the cells were trapped between fibers or inside fissures and crevices found in the fibers. Adherence of bacteria to the cotton fibers was clearly demonstrated by the scanning electron micrograph while almost no bacteria were found on the rayon fibers (Fig. 1). It also appeared that the cells did not selectively adhere to the end of the fibers or become trapped inside the crevices or fissures in the fibers (data not shown). The cross-sectional diameter of the rayon and cotton fibers appeared to be approximately equal at $20 \mu \mathrm{m}$. With the assumption that both fibers will be cylindrical when wet (22), the surface area of the cotton fibers can be estimated to be 1.5 times that of rayon since there are more fibers in cotton than rayon per unit weight. All cells were found as single cocci, further confirming the effectiveness of our methods of dispersal of bacterial clusters. Although quantitative measurements of adherence could not be performed with this method, these observations confirmed that the bacteria adhered primarily onto the surface of the cotton fibers.

Standardization of adherence assay. To ascertain the optimal conditions for further experiments, variables such as the concentration of bacteria, time of incubation, $\mathrm{pH}$, and temperature that might influence the adherence of bacteria to fibers were investigated.

In determining the optimal concentration of bacteria for adherence, various dilutions of strain DYAL were incubated with cotton disks for $30 \mathrm{~min}$ with agitation. As the quantities of bacteria were increased, more bacteria were found to be adherent to the cotton disk (Fig. 2). With the assumption that the binding is reversible and that the "binding site" on the fiber is univalent, it can be demonstrated with a Langmuir plot (data not shown) that the binding site is saturable. Saturation of the cotton disk appeared to occur at a bacterial inoculum of $3.2 \times 10^{9}$ cells. Under this condition, $\approx 2.7 \times 10^{8}(8.4 \%)$ cells remained adhered to each cotton disk. The adherence of bacteria to cotton fiber disks was extremely rapid and reached a plateau within $5 \mathrm{~min}$ (Fig. 3). The plateau remained stable for up to $60 \mathrm{~min}$ at which time bacterial adherence started to increase slowly. Notably, the specificity of staphylococcal adherence to pure fibers in the absence of serum factors can not be established with this data.

The binding of strain DYAL to cotton disk show little $\mathrm{pH}$ dependence. Within the $\mathrm{pH}$ range of 6.0 to 7.5 , the amount of bacteria adhering to the fiber remained unchanged (data not shown). Similarly, incubating the cells at either $23^{\circ} \mathrm{C}$ or $37^{\circ} \mathrm{C}$ did not result in any appreciable difference in adherence. Late log phase organisms appeared to be slightly more adherent than stationary phase cells (data not shown).
A

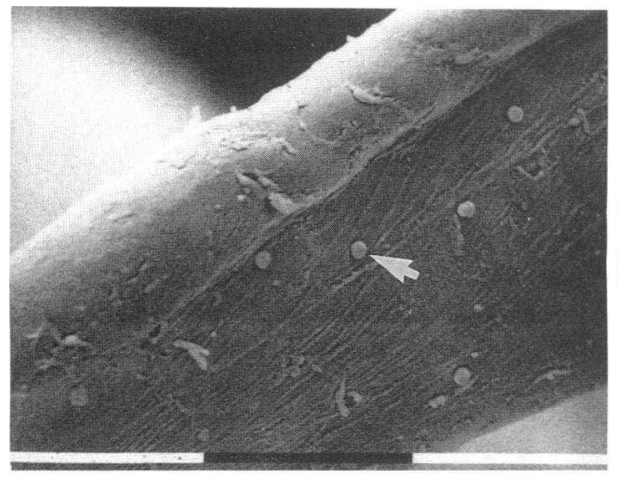

B

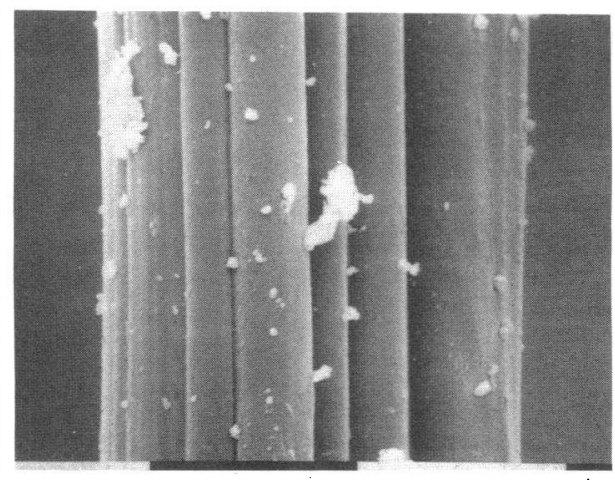

Figure 1. Scanning electron micrograph of the adherence of strain DYAL (white arrow) to $(a)$ a cotton fiber $(\times 2,500)$ and $(b)$ a rayon fibers $(\times 2,500)$. Each horizontal bar represents $10 \mu \mathrm{m}$. The material covering the fiber in $b$ represents fixing artifacts seen with rayon fibers. 


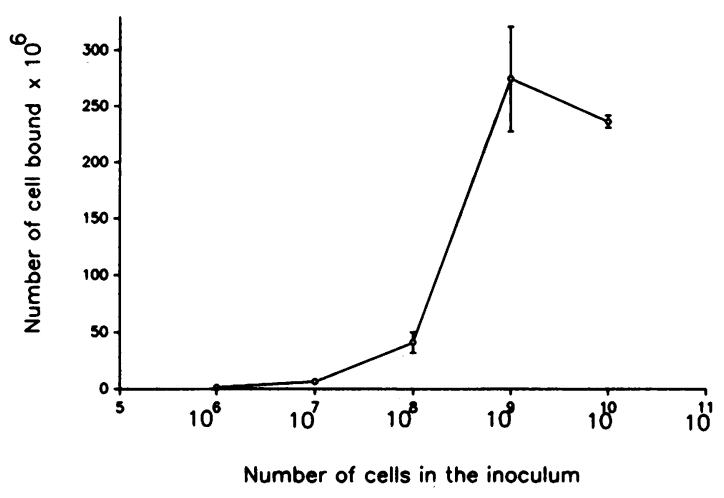

Figure 2. The effect of the bacterial concentration on adherence to cotton fibers. Cotton disks were incubated with various concentrations of strain DYAL for $30 \mathrm{~min}$. The disks were then washed with PBS and counted. The number of cells bound (mean \pm SEM) was derived from a standard curve of CFU vs. radioactive counts.

Based on these results, all subsequent adherence assays were performed at $23^{\circ} \mathrm{C}$ with agitation for $30 \mathrm{~min}$ with cells ( 2 $\mathrm{ml}$ vol) at a concentration of either $\approx 10^{8}$ or $\approx 10^{7}$ organisms per $\mathrm{ml}$.

Adherence to cotton and rayon fibers. Two $S$. aureus strains (DYAL and DB) and an $E$. coli strain were examined for their ability to adhere to fiber disks (cotton, rayon, or cotton with detergent). Using an inoculum of $\approx 100-300 \times 10^{6}$ radiolabeled cells, $14.8 \%$ (DYAL) or $25.2 \%$ (DB) of the inoculum bound to pure cotton disks compared with $1.2 \%$ (DYAL) or $3.6 \%$ (DB) bound to rayon disks (Table I). Only $0.27 \%$ and $0.12 \%$ of the inoculum of the $E$. coli strain was adherent to the cotton and rayon disks, respectively. Similar results were found for all strains using lower inocula $\left(\approx 10^{7}\right.$ cells) (data not shown). The difference in adherence between cotton and rayon fiber disks for the three strains of bacteria was probably larger than the data revealed since cotton imparted a $20 \%$ quenching effect on the total counts. Additional adherence assays comparing pure cotton and cotton with detergent $(0.37 \%$ Tween 20$)$ were also performed. As displayed in Table II, cotton disks with detergent were found to have reduced bacterial adherence $(0.35 \%$ [DYAL] or $2.76 \%$ [DB] of the inoculum bound) when compared to pure cotton fibers alone (5.94\% [DYAL] or $25.3 \%$ [DB] of the inoculum bound). Re-

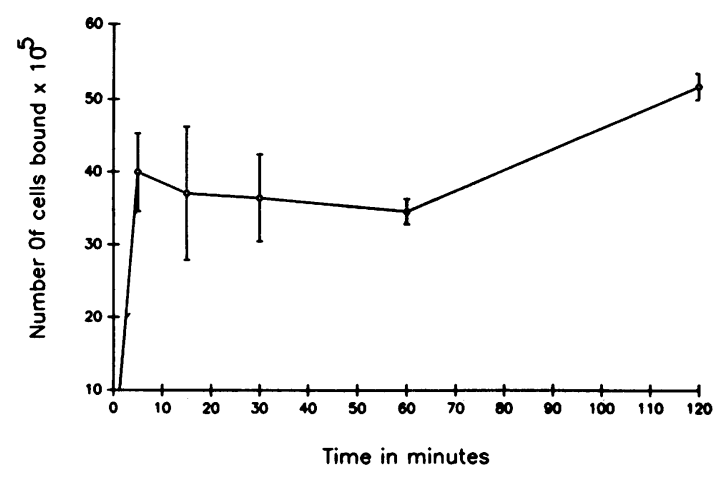

Figure 3. The effect of the time of incubation on bacterial adherence to cotton fibers. Cotton disks were incubated with strain DYAL (vol $2 \mathrm{ml}$ ) at a concentration of $1 \times 10^{8}$ organisms $/ \mathrm{ml}$ for varying periods of time. The number of cells bound were given as the mean \pm SEM. duction in bacterial adherence to detergent-treated fibers also occurred with $E$. coli (Table II). In general, the percentage of bound cells increased with a lower inoculum, suggesting that a fixed number of saturable sites may be present on the fibers. The results also revealed the two strains of $S$. aureus, which were isolated from blood and the vagina, to bind almost equally well to the same substrate (e.g., cotton fibers).

Effects of surface proteins on adherence to fibers. To evaluate the role of staphylococcal surface proteins in the adherence to the fibers, trypsinized or proteinase K-treated radiolabeled cells were incubated with fiber disks in the adherence assay. For most of the assays with rayon and cotton fibers with detergent, the radioactivity associated with cells adherent to the disk was not significantly above background, thus only data with cotton disks are presented. As shown in Table III, strains DYAL and DB treated with proteolytic enzymes demonstrated a marked decrease in adherence to cotton fibers. The reduction in adherence at $10^{8}$ cell concentration was greater for proteinase K-treated cells (from $15.6 \%$ bound to $1.29 \%$ and from $25.2 \%$ to $2.19 \%$ for strains DYAL and DB, respectively) than for trypsinized cells (from $15.6 \%$ to $4.35 \%$ [DYAL] and from $25.2 \%$ to $4.22 \%$ [DB]) when compared to untreated controls. Similar results were seen for both strains at a cell concentration of $\approx 10^{7}$ organisms $/ \mathrm{ml}$ (data not shown).

Immunoblots of cell-wall extracts with lysostaphin. To verify the effectiveness of proteolytic enzymes in the removal of staphylococcal surface proteins, equivalents amounts $(2 \mu \mathrm{l})$ of cell wall extracts from trypsin and proteinase-K treated cells as well as untreated controls were separated by SDS-PAGE, transferred to nitrocellulose and reacted with the chicken antisera to strain DB. In comparison to the cell wall extracts of untreated controls, all of the high molecular weight bands with a molecular size range of 120 to $220 \mathrm{kD}$ were susceptible to proteinase $\mathrm{K}$ (Fig. 4). However, sensitivity to trypsin digestion appeared to be more variable, with the lower band in the group more resistant to the enzyme (Fig. 4, open arrow). The possibility that a very small amount of free proteases might be present during lysostaphin digestion was ruled out since proteolytic activities as determined by azocoll and gelatin before extraction with lysostaphin did not reveal any residual proteases.

Using chicken anti-protein A IgG, we were able to demonstrate the heavily stained band with a molecular size of $\approx 50$ $\mathrm{kD}$ (Fig. 4, closed arrow) to be protein A. Notably, strain DYAL seemed to have a relative absence of protein $A$ as revealed by the blot. The relative deficiency in protein $A$ in strain DYAL was confirmed by Western blots in which the cell wall extract of strain DYAL immobilized on nitrocellulose was allowed to react separately with polyclonal sera against strain DB (Fig. 4), monoclonal mouse $\mathrm{IgG}_{1}$ directed against $M$ protein and chicken anti-protein A IgG (data not shown).

Thus, our data suggested that proteinase $\mathrm{K}$ was more effective than trypsin in digesting the surface-exposed proteins of $S$. aureus. Further, the differential sensitivities of the staphylococcal surface proteins to these proteases might possibly account for the difference in adherence to cotton fibers between trypsinized and proteinase K-treated cells.

Blocking adherence to cotton disks. To study the effect of defibrinated blood, or blood components on the adherence of $S$. aureus to the fibers and to avoid the nonspecific reaction between IgG and protein A, labeled DYAL cells, which are relatively deficient in protein $A$, were chosen to incubate with 
Table I. S. aureus Adherence to Cotton and Rayon Fibers*

\begin{tabular}{|c|c|c|c|c|c|}
\hline \multirow[b]{2}{*}{ Strains } & \multirow{2}{*}{$\begin{array}{l}\text { Inoculum } \\
\left(\mathrm{CFU} \times 10^{6}\right)\end{array}$} & \multicolumn{2}{|c|}{ Cotton disk } & \multicolumn{2}{|c|}{ Rayon disk } \\
\hline & & $\%$ bound $^{\ddagger}$ & $\left(\mathrm{CFU} \times 10^{6}\right)$ & $\%$ bound $^{\ddagger}$ & $\left(\mathrm{CFU} \times 10^{6}\right)$ \\
\hline DYAL & 200 & $14.8 \pm 3.18$ & $(29.7 \pm 6.4)$ & $1.20 \pm 0.10$ & $(2.38 \pm 0.20)$ \\
\hline DB & 320 & $25.20 \pm 1.50$ & $(80 \pm 4.8)$ & $3.60 \pm 0.36$ & $(11.7 \pm 0.11)$ \\
\hline C600NR & 120 & $0.27 \pm 0.006$ & $(0.32 \pm 0.007)$ & $0.12 \pm 0.02$ & $(0.145 \pm 0.025)$ \\
\hline
\end{tabular}

* Fiber disks were incubated with $2 \mathrm{ml}$ of bacterial suspensions at $23^{\circ} \mathrm{C}$ with agitation for $30 \mathrm{~min}$. The disks were washed with PBS and then counted. The number of adherent cells was derived from a standard curve of CFU vs. radioactive counts. All assays were performed in triplicate. ${ }^{\ddagger}$ Values are given in $\%$ bound \pm SEM (number of cells $\times 10^{6} \pm$ SEM). The percentage of bound cells were calculated by: CFU of adherent cells/inoculum $\times 100$.

cotton disks in the presence of different blood or serum components. HSA mixed with radiolabeled DYAL cells was immediately added to pure cotton disks in a competitive assay at two bacterial concentrations. This order of addition of reagents was necessary to avoid the precoating of cotton fibers with HSA. As seen in Fig. 5, the percentage of cells adherent to the cotton fibers decreased markedly even with a HSA concentration of $2 \mathrm{mg} / \mathrm{ml}$. There also appeared to be a dose-dependent reduction in adherence as the concentration of HSA was increased. At a concentration approaching that of serum (70 $\mathrm{mg} / \mathrm{ml}$ ), the inhibition of adhesion was complete. To confirm the hypothesis that the blocking of adherence by HSA was not due to the HSA coating of the bacteria, strain DYAL was preincubated with HSA for $30 \mathrm{~min}$ at a concentration of 10 $\mathrm{mg} / \mathrm{ml}$, pelleted $(7,000 \mathrm{~g} \times 10 \mathrm{~min})$, washed with $2 \mathrm{ml}$ of PBS, and incubated with cotton disks as in the standard assay. When comparing the adherence of precoated radiolabeled cells to that of control (no precoating), no significant difference in adherence was observed, suggesting that the effect of HSA on blocking bacterial adherence was due to the coating of the fibers with protein. This coating effect persisted even when the HSA-treated cotton disks were washed thoroughly before the addition of radiolabeled bacteria (Table IV).

The effect of blood or blood products on the adherence of staphylococcal cells was also studied. As shown in Table IV, preincubation of pure cotton disks with defibrinated blood resulted in an increase in bacterial adherence for strain DYAL (3.8\% bound) when compared to pretreatment with HSA $(0.21 \%)$. The increase in bacterial adherence was greater for defibrinated blood than for serum $(3.8 \%$ vs. $1.78 \%)$. On the other hand, adherence after preincubation with a mixture of fibronectin and HSA were the same as that of HSA alone $(0.17 \%$ vs. $0.21 \%)$. In fact, the counts per minute associated with adherent bacteria in the presence of HSA were only slightly above that of the background counts. Similarly, preincubation of cotton disks with HSA and murine monoclonal antibodies directed at nonstaphylococcal antigens did not enhance bacterial adherence above that of HSA controls. Likewise, when cotton disks were incubated with labeled DYAL cells and other serum components (i.e., fibronectin or murine monoclonal antibodies) in the presence of HSA in a competitive assay, staphylococcal adherence did not increase when compared to that of HSA alone (data not shown). Adherence to pure cotton fibers in the presence of any blood components was reduced when compared to cotton disks alone. In separate experiments, when trypsinized DYAL cells were used in the adherence study with defibrinated blood (Table V, $A$ ), the amount of adherent radiolabeled bacteria to pure cotton fibers was decreased when compared to untreated control $(0.55$ vs. $1.05 \%)$. More significant is the reduction in adherence when DYAL cells treated with proteinase $K$ were used instead of the trypsinized counterpart $(0.22$ vs. $0.55 \%)$ in the adherence assay.

Adherence assays with labeled DYAL cells and detergenttreated cotton disks were also performed (Table V, B). Bacterial adherence was found to be increased in the presence of defibrinated blood when compared to PBS controls (1.23\% vs. $0.37 \%)$. Of note is the fact that pure cotton disks when preincubated with defibrinated blood in parallel experiments exhibited similar adherence properties to that of cotton disks containing Tween 20 (1.05 vs. 1.23\%). Trypsinization and proteinase $\mathrm{K}$ treatment of DYAL cells resulted in a reduction in

Table II. S. aureus Adherence to Pure Cotton Fibers and Detergent-treated Fibers*

\begin{tabular}{|c|c|c|c|c|c|}
\hline \multirow[b]{2}{*}{ Strains } & \multirow{2}{*}{$\begin{array}{c}\text { Inoculum } \\
\left(\mathrm{CFU} \times 10^{6}\right)\end{array}$} & \multicolumn{2}{|c|}{ Cotton disk } & \multicolumn{2}{|c|}{ Cotton disk with Tween 20} \\
\hline & & $\%$ bound $^{\ddagger}$ & $\left(\mathrm{CFU} \times 10^{6}\right)$ & $\%$ bound $^{\ddagger}$ & $\left(\mathrm{CFU} \times 10^{6}\right)$ \\
\hline DYAL & 320 & $5.94 \% \pm 0.89$ & $(19.0 \pm 2.80)$ & $0.35 \% \pm 0.09$ & $(1.12 \pm 0.28)$ \\
\hline DB & 80 & $25.3 \% \pm 1.87$ & $(20.0 \pm 1.50)$ & $2.76 \% \pm 0.42$ & $(2.20 \pm 0.34)$ \\
\hline C600NR & 80 & $0.25 \% \pm 0.05$ & $(0.20 \pm 0.04)$ & $0.04 \% \pm 0.004 \%$ & $(0.032 \pm 0.003)$ \\
\hline
\end{tabular}

* Cotton disks were incubated with $2 \mathrm{ml}$ of bacterial suspensions at $23^{\circ} \mathrm{C}$ with agitation for $30 \mathrm{~min}$. The disks were then washed with PBS and counted. The number of CFU is deduced from a standard curve of CFU vs. radioactive counts. In some assays, cotton disks were precoated with $0.37 \%$ Tween 20 (wt \%). ${ }^{\ddagger}$ Values are given in $\%$ bound \pm SEM (number of cells $\times 10^{6} \pm$ SEM). 
Table III. The Effect of Proteolytic Enzymes on Staphylococcal Adherence*

\begin{tabular}{lccc}
\hline \multicolumn{1}{c}{ Strains (treatment) } & $\begin{array}{c}\text { Inoculum } \\
\left(\text { CFU } \times 10^{6}\right)\end{array}$ & $\begin{array}{c}\text { \% Bound to } \\
\text { cotton fibers }\end{array}$ & $\left(\right.$ CFU $\left.\times 10^{6}\right)$ \\
\hline DYAL (untreated) & 300 & $15.6 \% \pm 2.35$ & $(46.7 \pm 7.10)$ \\
DYAL (trypsinized) & 400 & $4.35 \% \pm 0.10$ & $(17.4 \pm 0.38)$ \\
DYAL (proteinase K) & 320 & $1.29 \% \pm 0.15$ & $(4.13 \pm 0.48)$ \\
DB (untreated) & 320 & $25.2 \% \pm 1.50$ & $(80.5 \pm 4.80)$ \\
DB (trypsinized) & 391 & $4.22 \% \pm 0.34$ & $(16.5 \pm 1.30)$ \\
DB (proteinase K) & 393 & $2.19 \% \pm 0.22$ & $(8.62 \pm 0.86)$ \\
& & & \\
\hline
\end{tabular}

* Cotton disks were incubated with $2 \mathrm{ml}$ of bacterial suspensions at $23^{\circ} \mathrm{C}$ with agitation for $30 \mathrm{~min}$. The disks were then washed with PBS and counted. The number of CFU is deduced from a standard curve of CFU vs. radioactive counts. In these assays, some of the cells have been treated with either trypsin or proteinase $\mathrm{K}$ to remove surface proteins.

${ }^{\ddagger}$ Values are given in $\%$ bound \pm SEM (number of cells $\times 10^{6} \pm \mathrm{SEM}$ ).

bacterial adherence to detergent-treated fibers. This degree of reduction in adherence with protease-treated DYAL cells was comparable to those of pure cotton fibers precoated with defibrinated blood. Adherence studies with detergent-treated cotton disks preincubated with serum, HSA, HSA with fibronectin, and HSA with murine monoclonal $\operatorname{IgG}_{1}$ were also performed. However, the radioactivities associated with cells adherent to pretreated disks were less than that of disks prein-
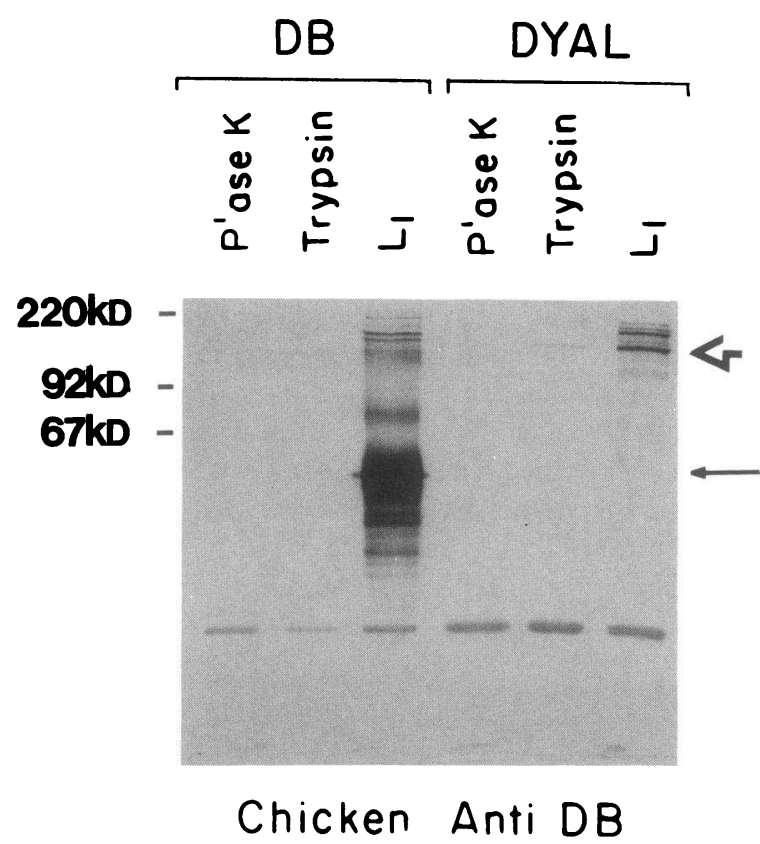

Figure 4. Immunoblot of cell wall extracts of strains DYAL and DB before $\left(\mathrm{L}_{1}\right)$ and after treatment with trypsin or proteinase $K$ (P'ase K). The cell wall extract $(8 \mu \mathrm{l})$ was diluted with $32 \mu \mathrm{l}$ of water and 40 $\mu$ l of sample buffer (16); $20 \mu$ l of the boiled sample was applied to a 9\% SDS gel. After electrophoresis, the proteins were electroblotted onto nitrocellulose and probed with chicken antisera to a blood isolate strain DB. The open arrow indicates the lower band of the high mol wt proteins; the closed arrow indicates protein A. Size standards are represented at the left of the figure.

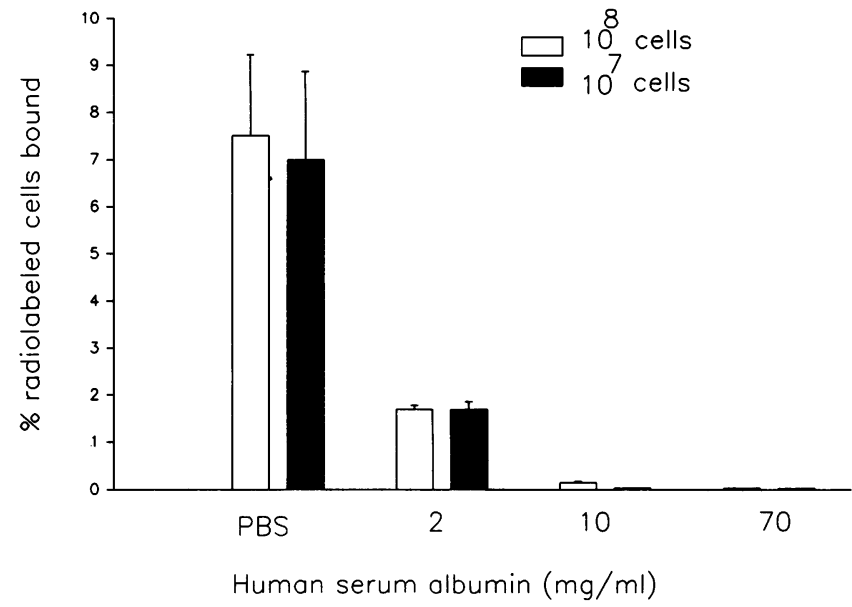

Figure 5. The effect of human serum albumin on staphylococcal adherence to cotton fibers. Various concentrations of HSA $(\mathrm{mg} / \mathrm{ml})$ mixed with either $10^{8}$ or $10^{7}$ labeled DYAL cells were incubated with cotton disks for $30 \mathrm{~min}$. The cotton disks were washed with PBS and counted for radioactivity. The percentage of bound cells (mean \pm SEM) were calculated by: CFU of adherent cells/inoculum $\times 100$.

cubated with PBS alone and thus represented CPM not significantly above background (data not shown).

\section{Discussion}

These studies demonstrate that staphylococcal adherence to pure fibers such as cotton is a rapid and saturable process. This process appeared to be independent of temperature $\left(22^{\circ}\right.$ and $\left.37^{\circ} \mathrm{C}\right)$ and $\mathrm{pH}(6.0$ to 7.5$)$. The fact that the bacteria are more adherent to pure cotton than to rayon suggested that there is

Table IV. The Effect of Blood Products on Staphylococcal Adherence*

\begin{tabular}{lc}
\hline & DYAL cells inoculum $200 \times 10^{6}$ \\
\hline Control PBS & $14.76 \% \pm 2.59^{\ddagger}$ \\
& $(29.5 \pm 5.18)$ \\
Blood & $3.80 \% \pm 0.28$ \\
& $(7.60 \pm 0.56)$ \\
Serum & $1.78 \% \pm 0.19$ \\
HSA & $(3.56 \pm 0.38)$ \\
& $0.21 \% \pm 0.02$ \\
HSA and fibronectin & $(0.42 \pm 0.04)$ \\
& $0.17 \% \pm 0.033$ \\
HSA and murine & $(0.34 \pm 0.07)$ \\
monoclonal IgG & $0.26 \% \pm 0.056$ \\
\end{tabular}

* After preincubation with the respective blood components or controls for 30 min, cotton disks were washed with PBS and further incubated with $2 \mathrm{ml}$ of bacterial suspensions (strain DYAL) for another $30 \mathrm{~min}$. The disks were subsequently washed with PBS and counted. The number of adherent cells was derived from a standard curve of CFU vs. radioactive counts.

${ }^{\ddagger}$ Values are given in $\%$ bound \pm SEM (number of cells $\times 10^{6} \pm$ SEM). 
Table V. The Effect of Proteolytic Enzymes on Staphylococcal Adherence to Cotton Fibers in the Presence of Defibrinated Blood*

\begin{tabular}{|c|c|c|c|}
\hline & DYAL cells & $\begin{array}{l}\text { DYAL cells } \\
\text { trypsinized }\end{array}$ & $\begin{array}{c}\text { DYAL cells } \\
\text { proteinase } \mathrm{K} \text { treated }\end{array}$ \\
\hline & Inoculum $320 \times 10^{6}$ & Inoculum $320 \times 10^{6}$ & Inoculum $320 \times 10^{6}$ \\
\hline \multicolumn{4}{|c|}{ A Cotton disk preincubated with } \\
\hline (i) Blood & $\begin{array}{r}1.05 \% \pm 0.09^{\ddagger} \\
(3.36 \pm 0.28)\end{array}$ & $\begin{array}{c}0.55 \% \pm 0.11 \\
(1.74 \pm 0.36)\end{array}$ & $\begin{array}{c}0.22 \% \pm 0.03 \\
(0.69 \pm 0.09)\end{array}$ \\
\hline (ii) PBS control & $\begin{array}{c}5.04 \% \pm 0.93 \\
(16.1 \pm 2.97)\end{array}$ & & \\
\hline \multicolumn{4}{|c|}{$\begin{array}{l}\text { B Cotton disk with } 0.37 \% \\
\text { Tween } 20 \text { preincubated with }\end{array}$} \\
\hline (i) Blood & $\begin{array}{c}1.23 \% \pm 0.22 \\
(3.94 \pm 0.72)\end{array}$ & $\begin{array}{r}0.63 \pm 0.08 \\
(2 \pm 0.25)\end{array}$ & $\begin{array}{r}0.21 \pm 0.025 \\
(0.66 \pm 0.08)\end{array}$ \\
\hline (ii) PBS control & $\begin{array}{c}0.37 \pm 0.06 \\
(1.18 \pm 0.18)\end{array}$ & & \\
\hline
\end{tabular}

* After preincubation with defibrinated blood for $30 \mathrm{~min}$, pure cotton disks or disks with $0.37 \%$ Tween 20 (wt \%) were washed with PBS and further incubated with $2 \mathrm{ml}$ of bacterial suspensions (strain DYAL). The disks were then washed with PBS and counted. The number of adherent cells was derived from a standard curve of CFU vs. radioactive counts. ${ }^{\ddagger}$ Values are given in $\%$ bound \pm SEM (number of cells $\times 10^{6} \pm \mathrm{SEM}$ ).

some degree of substrate preference in staphylococcal adherence since both cotton and rayon have comparable surface area per unit weight. Both cotton and rayon are hydrophilic macromolecules. Cotton is a natural product composed of pure cellulose, a polysaccharide with D-glucose subunits linked in a $\beta-4-O$ manner (22). Rayon, in contrast, is a manufactured product that is comprised of regenerated cellulose (22). Cotton cellulose differs from rayon cellulose primarily in the higher degree of polymerization inherent in cotton cellulose. This property has conferred on cotton a more crystalline structure and thus may constitute a different surface charge from that of rayon. In addition, natural cotton has an outer hydrophobic waxy layer. Although most of the waxy layers are expected to be removed during treatment with boiling isopropanol, residual wax may have constituted regions of hydrophobicity. It is likely that the surface charge or hydrophobicity of washed cotton fibers differs from rayon in such a way that $S$. aureus adhered to them differently. Similarly, reduction in bacterial adherence to cotton fibers precoated with a detergent such as Tween 20 also demonstrated the importance of surface charge and/or hydrophobicity in initiating nonspecific adherence mechanisms. Although the interaction between staphylococcal surface proteins and cotton fibers appeared to be nonspecific, this initial event may be necessary to promote colonization and further potentiate specific adherence mechanisms.

The adherence of $S$. aureus to these fiber materials is not unique to TSS strains since both the TSS strain (DYAL) and the blood isolate (DB) bound well to cotton fibers in our studies. Recent studies have demonstrated that $S$. aureus strains isolated from various infectious sources generally possess high surface hydrophobicity compared to strains isolated from the environment (23). It has been suggested that $S$. aureus strains acquire the ability to colonize inanimate surfaces such as intravascular catheters, sutures, and tissue prostheses $(24,25)$ by using hydrophobic surface proteins in the first step of adhesion.

Adherence studies with trypsinized and proteinase $\mathrm{K}$ treated cells revealed that surface proteins were probably involved in the attachment of staphylococcal cells to pure cotton fibers. There was also a correlation between the degree of proteolysis of surface proteins and the reduction in adherence as demonstrated by the immunoblot and adherence assays when comparing trypsinized and proteinase $\mathrm{K}$-treated cells. In previous studies of bacterial adherence to inanimate and mucosal surfaces, components on the surface of bacterial cells have been shown to be important in determining their ability to adhere $(24,26-31)$. The presence of pili on gonococci correlates with adherence and with pathogenicity. Surface $M$ protein and lipoteichoic acid in Streptococcus pyogenes have been shown to be important determinants in their ability to adhere to specific surfaces $(28,30)$. However, bacterial adhesion to inanimate surfaces in the absence of blood or serum proteins appeared to be nonspecific and may be a function of the hydrophobic and charge characteristics of the particular surface (31).

The study of bacterial adhesion to artificial surfaces is further complicated by the presence of blood or blood components $(26,32)$, fibrin-platelet thrombi $(29)$, and tissue fluid (33). HSA, the major protein in all human blood (34), was found to inhibit adherence of labeled DYAL strain to cotton fibers in a dose-dependent fashion. The inhibition was probably due to a coating effect of the cotton fiber by the protein (Table IV). Remarkably, the decrease in staphylococcal adherence persisted even when the fiber disks were washed extensively with PBS before the addition of radiolabeled bacteria. This would imply that either HSA has a high affinity for cotton fibers or it competitively binds to the same site used by the staphylococcus. The interaction may be through hydrophobic interactions since HSA is a protein molecule with exposed hydrophobic domains (35). Defibrinated blood containing HSA at serum concentration, on the other hand, was able to restore a moderate amount of adherence compared to HSA alone ( 3.8 vs. $0.21 \%$ [Table IV]). This would suggest that a specific component or components in defibrinated blood competitively binds first to the cotton fibers in the presence of HSA thus allowing for the adherence of labeled DYAL cells.

Adherence of labeled DYAL cells to detergent-treated fiber disks preincubated with defibrinated blood resulted in an in- 
crease in bacterial adherence compared to PBS controls (Table V). The percentage of the inoculum bound to the detergentcontaining disk is almost the same as that of pure cotton disk preincubated with defibrinated blood (1.23 vs. $1.05 \%)$. This mode of adherence suggested the importance of coating of fiber disks by blood factors that mediate staphylococcal adherence. The manner by which bacterial adherence to the precoated disks occurs also appeared to be more specific since it is independent of the surface constituents of the fibers employed in the adherence assays. Adherence studies of labeled DYAL cells which have been treated with trypsin or proteinase $\mathrm{K}$ demonstrated the role of staphylococcal surface proteins in mediating adherence to blood component or components that coated these fibers. Since these detergent-coated disks contain the same materials found in some commercially available cotton tampons, the role of staphylococcal surface proteins in mediating bacterial adherence to actual tampon fibers in the presence of defibrinated blood may have clinical relevance.

Previous studies $(26,29,36,37)$ have stressed the importance of fibronectin in the adherence of $S$. aureus to tissues, fibrin-platelet thrombi and indwelling catheters. In relation to vaginal TSS cases, Antonas et al. have found the concentration of fibronectin in the vaginal fluid to vary between 5 and 120 $\mu \mathrm{g} / \mathrm{ml}$ (38). Further, fibronectin, which was shown to be adherent to commercial tampon fibers, was postulated to be the adherence factor for $S$. aureus to colonize tampon or vaginal mucosa during menstruation. The results of our adherence studies, however, minimized the part played by fibronectin in the adherence of a TSS strain to cotton fibers. One reason may be that HSA, in concentrations found in menstrual blood, coats the fiber, thus blocking adherence of the TSS strain even in the presence of fibronectin.

Since most mammalian polyclonal IgG contains antibodies directed towards surface antigens of $S$. aureus (39), we used murine monoclonal $\mathrm{IgG}_{1}$ to a nonstaphylococcal antigen to study the effect of immunoglobulin on the adherence of $S$. aureus to fibers. Protein A negative strain DYAL also allowed us to examine the role of surface proteins other than protein $A$ in staphylococcal adherence to cotton fibers. Results revealed that the murine monoclonal antibodies did not increase staphylococcal adherence to cotton fibers in the presence of HSA.

Cotton disks preincubated with serum containing HSA at $70 \mathrm{mg} / \mathrm{ml}$ also displayed augmented adherence in comparison to disks pretreated with HSA or HSA with fibronectin. Nonetheless, the increase observed was less than that of disks preincubated with blood (1.78 vs. $3.8 \%$ [Table IV]). This finding is consistent with the idea that two or more blood or serum components might be involved simultaneously in promoting adherence of $S$. aureus to cotton fibers. These results lead one to speculate that other serum components adherent to an inanimate surface might mediate staphylococcal attachment.

Our data indicated that surface proteins of $S$. aureus were accountable for the increased adherence to cotton fibers (with or without prior detergent treatment) in the presence of serum or blood compared to HSA controls. It also appeared that two or more staphylococcal surface proteins may be involved in the adherence to serum or blood proteins since reduction in staphylococcal adherence to cotton fibers in the presence of defibrinated blood was more significant with proteinase $K$ treated cells than with trypsinized cells (Tables IV and V). This explanation is supported by the results that trypsinization of strain DYAL did not remove all the surface proteins whereas proteinase $\mathrm{K}$ did (Fig. 4).

It would appear from our results that $S$. aureus employs more than one mechanism (i.e., multiple surface proteins) to adhere to cotton fibers in the presence of blood or serum. Multiple adhesive mechanisms would require the target or target tissue to display more than one type of receptor (serum or blood components) before optimal adhesion can be achieved. These requirements also minimize the chances of coincidental attachment to nontargeted areas (27). Thus, the attachment of a TSS strain to fibers through blood and serum components would seem to be more specific than that of fiber alone.

The hypothesis that the interaction between blood and cotton fibers altered staphylococcal adherence is suggested by our data. It appeared that bacterial adherence to specific blood factors coating these fibers may be a common pathway by which $S$. aureus cells adhere to a variety of inanimate surfaces. Whether adherent $S$. aureus cells exhibit selective changes in the metabolic activities to affect production of TSS associated toxin is not known. Nonetheless, the importance of staphylococcal surface proteins in mediating adherence of $S$. aureus to commercially available tampon fibers and surgical packing cannot be underestimated.

\section{Acknowledgments}

We thank Tracy Guinta for excellent help in animal work.

This work was supported by a grant from Playtex Family Products, Inc., Paramus, NJ.

\section{References}

1. Chesney, P. J., M. S. Bergdoll, J. P. Davis, and J. M. Bergeront. 1984. The disease spectrum, epidemiology, and etiology of toxic shock syndrome. Annu. Rev. Microbiol. 38:315-338.

2. Reingold, A. L. 1983. Nonmenstrual toxic shock syndrome: the growing picture. J. Am. Med. Assoc. 249:932.

3. Jacobson, J. A., and E. M. Kasworm. 1986. Toxic shock syndrome after nasal surgery. Case reports and analysis of risk factors. Arch. Otolaryngol. Head Neck. Surg. 112:329-332.

4. Toback, J., and J. W. Fayerman. 1983. Toxic shock syndrome following septorhinoplasty. Implications for the head and neck surgeon. Arch. Otolaryngol. Head Neck Surg. 109:627-629.

5. Blomster-Hautamaa, D. A., B. N. Kreiswirth, J. S. Kornblum, R. P. Novick, and P. M. Schlievert. 1986. The nucleotide and partial amino acid sequence of toxic shock syndrome toxin-1. J. Biol. Chem. 261:15783-15786.

6. Arko, R. J., J. K. Rasheed, C. V. Broome, F. W. Chandler, and A. L. Paris. 1984. A rabbit model of toxic shock syndrome: clinicopathological features. J. Infect. 8:205-211.

7. Broome, C. V., P. S. Hayes, G. W. Ajello, J. C. Feeley, R. J. Gibson, L. M. Graves, G. A. Hancock, R. L. Anderson, A. K. Highsmith, D. C. Mackel, N. J. Hargrett, and A. C. Reingold. 1982. In-vitro studies of interaction between tampon and Staphylococcus aureus. Ann. Intern. Med. 96:959-962.

8. Schlievert, P. M., D. A. Blomster, and J. A. Kelly. 1984. Toxic shock syndrome Staphylococcus aureus: effect of tampons on toxic shock syndrome toxin 1 production. Obstet. Gynecol. 64:666-671.

9. Robbins, R. N., R. F. Reiser, G. L. Hehl, and M. S. Bergdoll. 1987. Production of toxic shock syndrome toxin 1 by Staphylococcus aureus as determined by tampon disk-membrane-agar method. $J$. Clin. Microbiol. 25:1446-1449.

10. Lee, A. C., B. A. Crass, and M. S. Bergdoll. 1987. Investigation 
by syringe method of effect of tampons on productions in vitro of toxic shock syndrome toxin 1 by Staphylococcus aureus. J. Clin. Microbiol. 25:87-90.

11. Reiser, R. F., S. J. Hinzman, and M. S. Bergdoll. 1987. Production of toxic shock syndrome toxin 1 by Staphylococcus aureus restricted to endogenous air in tampons. J. Clin. Microbiol. 25:14501452.

12. Ingham, E., E. A. Eady, K. T. Holland, and G. Gowland. 1985. Effects of tampon materials on the in-vitro physiology of a toxic shock syndrome strain of Staphylococcus aureus. J. Med. Microbiol. 20:8795.

13. Holland, K. T., E. Ingham, E. A. Eady, and G. Gowland. 1985. Toxic shock syndrome: the effect of solid phase materials on the physiology of Staphylococcus aureus. Postgrad. Med. J. 61(Suppl. 1):39-43.

14. Cheung, A. L., and V. A. Fischetti. 1988. Variation in the expression of cell wall proteins of Staphylococcus aureus grown on solid and liquid media. Infect. Immun. 56:1061-1065.

15. Fischetti, V. A., F. Chapman, E. Grun, and J. B. Zabriskie. 1989. Role of air in growth and production of TSST-1 by Staphylococcus aureus in experimental cotton and rayon tampons. Rev. Infect. Dis. 11(Suppl.1):176-181.

16. Van de Rijn, I., and R. E. Kessler. 1980. Growth characteristics of group A streptococci in a new chemically defined medium. Infect. Immun. 27:444-448.

17. Fischetti, V. A., K. F. Jones, B. N. Manjula, and J. R. Scott. 1984. Streptococcal M6 protein expressed in Escherichia coli. Localization, purification, and comparison with streptococcal-derived $\mathbf{M}$ protein. J. Exp. Med. 159:1083-1095.

18. Laemmli, U. K. 1970. Cleavage of structural proteins during the assembly of the head of bacteriophage T4. Nature (Lond.) 227:680-685.

19. Towbin, H., T. Staehelin, and J. Gordon. 1979. Electrophoretic transfer of proteins from polyacrylamide gels to nitrocellulose sheets: Procedure and some applications. Proc. Natl. Acad. Sci. USA. 76:4350-4354.

20. Blake, M. S., K. H. Johnston, G. J. Russell-Jones, and E. C. Gotschlich. 1984. A rapid sensitive method for detection of alkaline phosphatase-conjugated anti-antibody on Western blots. Anal. Biochem. 136:175-179.

21. Kondo, I. 1978. Biological application. In Principles and Techniques of Scanning Electron Microscopy. Vol 6. M. A. Hayat, editor. Van Nostrand Reinhold Co., New York. 309-316.

22. Winch, A. R. 1984. Cotton, a truly broad spectrum performance fiber: the basis for sustained positions of market strength. In Nonwovens Symposium. Tappi Press, Atlanta, GA. 151-172.

23. Ljungh, Å., S. Hjerten, and T. Wadström. 1985. High surface hydrophobicity of autoaggregating Staphylococcus aureus strains isolated from human infections studied with the salt aggregation test. Infect. Immun. 47:522-526.

24. Barrett, S. P. 1985. Protein mediated adhesion of Staphylococ- cus aureus to silicone implant polymer. J. Med. Microbiol. 20:249253.

25. Ludwicka, A., B. Jansen, T. Wadström, L. Switalski, G. Peters, and G. Pulverer. 1984. Attachment of staphylococci to various synthetic polymers. Zbl. Bakt. Hyg. A. 256:479-489.

26. Vaudaux, P. E., F. A. Waldvogel, J. J. Morgenthaler, and U. E. Nydegger. 1984. Adsorption of fibronectin onto polymethylmethacrylate and promotion of Staphylococcus aureus adherence. Infect. Immun. 45:768-774.

27. Christensen, G., W. A. Simpson, and E. Beachey. 1986. Adhesion of bacteria to animal tissue: Complex mechanisms. In Bacterial Adhesion. D. C. Savage, and M. Fletcher, editors. Plenum Publishing Corp., New York. 279-306.

28. Ellen, R. P., and R. J. Gibbons. 1972. M protein-associated adherence of Streptococcus pyogenes to epithelial surfaces. Infect. Immun. 5:826-830.

29. Toy, P. T. C. Y., L. W. Lai, T. A. Drake, and M. A. Sande. 1985. Effect of fibronectin on adherence of Staphylococcus aureus to fibrin thrombi in vitro. Infect. Immun. 48:83-86.

30. Beachey, E. H., and I. Ofek. 1976. Epithelial cell binding of group A streptococci by lipoteichoic acid on fimbriae denuded of $\mathbf{M}$ protein. J. Exp. Med. 143:759-771.

31. Christensen, G. D., W. A. Simpson, and E. H. Beachey. 1985. Bacterial adherence in infection. In Principles and Practice of Infectious Diseases. G. L. Mandell, R. G. Douglas, and J. E. Bennett, editors. John Wiley and Sons, New York. 6-23.

32. Ogawa, S. K., E. R. Yurberg, V. Hatcher, M. A. Levitt, and F. D. Lowy. 1985. Bacterial adherence to human endothelial cells in vitro. Infect. Immun. 50:218-224.

33. Katz, S. K., M. Ishar, and D. Mirelman. 1980. Bacterial adherence to surgical sutures. Ann. Surg. 194:35-41.

34. Bussing, H. J. 1957. The biochemistry of menstrual blood. Zentralbl. Gynaekol. 79:456-467.

35. Wadström, T. 1987. Molecular aspects on pathogenesis of wound and foreign body infections due to staphylococci. Z Zl. Bakteriol. Mikrobiol. Ser. Hyg. A. 266:191-211.

36. Proctor, R. A., D. F. Mosher, and P. J. Olbrantz. 1982. Fibronectin binding to Staphylococcus aureus. J. Biol. Chem. 257:1478814794.

37. Russell, P. B., J. Kline, M. C. Yoder, and R. A. Polin. 1987. Staphylococcal adherence to polyvinyl chloride and heparin-bonded polyurethane catheters is species dependent and enhanced by fibronectin. J. Clin. Microbiol. 25:1083-1087.

38. Antonas, K. N., D. M. Yajko, and W. K. Hadley. 1983. Assay of fibronectin in vaginal fluid and role of fibronectin in bacterial colonization. Abstracts of the 83rd Annual Meeting of the American Society for Microbiology 25. (Abstr.)

39. Bell, J. A., T. H. Pennington, and D. T. Petrie. 1987. Western blot analysis of staphylococcal antibodies present in human sera during health and disease. J. Med. Microbiol. 23:95-99. 